Jurnal Kependudukan Indonesia | Edisi Khusus Demografi dan COVID-19, Juli 2020 | 43-48

JURNAL KEPENDUDUKAN INDONESIA

p-ISSN : 1907-2902 (Print)

e-ISSN : 2502-8537 (Online)

\title{
DAMPAK PANDEMI COVID-19 TERHADAP PHK DAN PENDAPATAN PEKERJA DI INDONESIA
}

\section{(THE IMPACT OF COVID-19 ON WORKER LAYOFFS AND INCOME IN INDONESIA)}

\author{
Ngadi, Ruth Meilianna*, Yanti Astrelina Purba \\ Pusat Penelitian Kependudukan, Lembaga Ilmu Pengetahuan Indonesia \\ *Korespondensi penulis: ruthmeilianna56@gmail.com
}

\begin{abstract}
The larger-scale social restrictions policy to handling the COVID-19 pandemic had an impact on the socio-economic of the community including job sustainability and income of workers. This study analyzes the impact of the COVID-19 on worker layoffs and income in Indonesia. This research uses an accidental sampling through the online survey. The results showed that COVID-19 had an impact on layoffs and decreased income, especially during the social distancing. The result showed that layoffs of workers in Indonesia amounted to 15.6 percent. Regarding income, about 31.0 percent of workers claim that their income has decreased by less than 50 percent and 8.6 percent of that has fallen above 50 percent. The government needs to conduct strict supervision of companies in each region. The role of the community is needed in overcoming existing problems by looking for new strategies that are utilizing technology and looking for new job opportunities, while still paying attention to health protocols.
\end{abstract}

Keywords: COVID-19, worker, layoffs, income, Indonesia

Pandemi COVID-19 yang terjadi di Indonesia menyebabkan pemerintah menerapkan kebijakan Pembatasan Sosial Berskala Besar (PSBB) di beberapa daerah. Kebijakan tersebut mengubah aktivitas sosial ekonomi masyarakat seperti transportasi terbatas, pusat perbelanjaan, tempat rekreasi dan hiburan ditutup. Keadaan ini berdampak luas terhadap kondisi sosial ekonomi masyarakat termasuk keberlangsungan pekerjaan dan penurunan pendapatan pekerja. Pada fase awal International Labour Organization (ILO) memperkirakan bahwa sekitar 25 juta pekerjaan di dunia dapat hilang disebabkan oleh pandemi COVID19 (ILO, 2020a). Selanjutnya pada kuartal kedua tahun 2020 ILO memprediksi jam kerja seluruh pekerja akan menurun 10,5 persen atau setara dengan 305 juta pekerja penuh waktu dengan asumsi jam kerja penuh waktu adalah 48 jam perminggu (ILO, 2020c).
Oleh sebab itu, Pusat Penelitian Kependudukan LIPI bersama dengan Lembaga Demografi Universitas Indonesia (LD-UI) dan Badan Penelitian dan Pengembangan Kementerian Ketenagakerjaan melaksanakan survei online tentang dampak COVID19 terhadap tenaga kerja. Survei dilakukan pada tanggal 24 April- 02 Mei 2020 dengan total responden sebanyak 1.112 buruh/karyawan/pegawai. Adapun metode sampling yang digunakan adalah Accidental Sampling dengan pembobotan. Penghitungan bobot variabel sampel menggunakan data Sakernas Agustus 2019. Bobot ini merepresentasikan besaran karakteristik populasi yang diwakili oleh setiap unit sampel. Pembobotan didasarkan pada variabel demografi jenis kelamin dan usia. 
Tabel 1.

PHK dan Perubahan Pendapatan Buruh/Pegawai/Karyawan Menurut Jenis Kelamin, Usia, dan Lapangan Pekerjaan

\begin{tabular}{|c|c|c|c|c|c|c|c|c|}
\hline \multirow[b]{2}{*}{ Kategori } & \multicolumn{3}{|c|}{ PHK (\%) } & \multicolumn{4}{|c|}{ Perubahan pendapatan (\%) } & \multirow[b]{2}{*}{$\mathrm{n}$} \\
\hline & Total & $\begin{array}{c}\text { Tanpa } \\
\text { Pesangon } \\
\end{array}$ & $\begin{array}{c}\text { Dengan } \\
\text { Pesangon } \\
\end{array}$ & $\begin{array}{c}\text { Menurun } \\
<50 \%\end{array}$ & $\begin{array}{c}\text { Menurun } \\
\geq 50 \%\end{array}$ & $\begin{array}{c}\text { Tetap/ } \\
\text { meningkat }\end{array}$ & $\begin{array}{l}\text { Tidak ada } \\
\text { pendapatan }\end{array}$ & \\
\hline Total & 15,6 & 13,8 & 1,8 & 31 & 8,6 & 45,3 & 15,3 & 100744 \\
\hline \multicolumn{9}{|l|}{ Jenis Kelamin } \\
\hline Laki-laki & 16,7 & 2,8 & 13,9 & 34,2 & 9,6 & 41,5 & 14,7 & 54.720 \\
\hline Perempuan & 14,2 & 0,6 & 13,6 & 27 & 7,5 & 49,8 & 15,8 & 46.074 \\
\hline \multicolumn{9}{|l|}{ Usia } \\
\hline $15-24$ & 34,5 & 1,1 & 33,5 & 22,5 & 8,1 & 40,3 & 29,2 & 10.701 \\
\hline $25-34$ & 13,8 & 2,1 & 11,7 & 33,3 & 7,2 & 47,5 & 12 & 33.379 \\
\hline $35-44$ & 13,7 & 2,1 & 11,7 & 33,5 & 8,6 & 43,5 & 14,4 & 26.524 \\
\hline $45-54$ & 16,2 & 0,9 & 15,3 & 29,4 & 7,5 & 43,1 & 20 & 18.679 \\
\hline $55-64$ & 7,4 & 2,9 & 4,5 & 26,4 & 11,6 & 56,1 & 5,9 & 10.509 \\
\hline $65+$ & 0 & 0 & 0 & 50 & 50 & 0 & 0 & 952 \\
\hline \multicolumn{9}{|l|}{ Jenis jabatan/pekerjaan } \\
\hline $\begin{array}{l}\text { Kepemimpinan dan } \\
\text { ketatalaksanaan }\end{array}$ & 10,3 & 2,8 & 7,5 & 29,7 & 7 & 52,9 & 10,5 & 15.077 \\
\hline $\begin{array}{l}\text { Profesional, teknisi dan } \\
\text { yang sejenis }\end{array}$ & 7,9 & 2,7 & 16,8 & 43,8 & 12,7 & 26,5 & 17 & 11.033 \\
\hline $\begin{array}{l}\text { Produksi, operator alat } \\
\text { angkutan dan pekerja } \\
\text { kasar }\end{array}$ & 19,5 & 1,1 & 6,8 & 32,6 & 6,4 & 52,4 & 8,6 & 33.099 \\
\hline $\begin{array}{l}\text { Tata usaha dan yang } \\
\text { sejenis }\end{array}$ & 15,6 & 0,4 & 15,2 & 27,7 & 8 & 50,7 & 13,6 & 15.129 \\
\hline Usaha jasa & 28,3 & 2,7 & 25,5 & 23,6 & 9,8 & 38,2 & 28,4 & 18.383 \\
\hline Usaha penjualan & 26,4 & 2,9 & 23,5 & 32,3 & 15,6 & 26,3 & 25,7 & 6.352 \\
\hline $\begin{array}{l}\text { Usaha pertanian, } \\
\text { kehutanan, perburuan, } \\
\text { dan perikanan }\end{array}$ & 9 & 0 & 9 & 27,6 & 5 & 62,4 & 5 & 1.672 \\
\hline
\end{tabular}

Hasil penelitian menunjukan terjadinya gelombang Pemutusan Hubungan Kerja (PHK) dan penurunan pendapatan buruh/karyawan/pegawai selama masa PSBB di Indonesia. Persentase PHK buruh/pegawai/karyawan di Indonesia pada akhir April 2020 sebesar 15,6 persen yang terdiri dari 1,8 persen PHK dengan pesangon dan 13,8 persen PHK tanpa pesangon.

Tabel 1 menunjukkan persentase yang hampir berimbang antara korban PHK tenaga kerja laki-laki dan perempuan, yaitu masing-masing 16,7 persen dan 14,2 persen. Persentase PHK tenaga kerja karena COVID-19 dari hasil penelitian ini tampak lebih besar dari prediksi ILO yaitu 10,5 persen pada kuarta kedua tahun 2020. Namun angka PHK tersebut hampir sama dengan angka PHK di Amerika Serikat yang pada Juli 2020 sebesar 14,7 persen (Ziv, 2020). Bahkan Cox (2020) memprediksi pengangguran di Amerika Serikat akan mencapai 32,1 persen sebagai dampak COVID19. Besarnya pengaruh COVID-19 dijelaskan oleh Ozili (2020) bahwa gangguan ekonomi tiba-tiba yang disebabkan oleh COVID-19 tidak hanya merusak tetapi juga memiliki dampak berlebih karena menciptakan guncangan permintaan dan penawaran di hampir setiap bidang usaha. Pandemi COVID-19 juga berdampak terhadap penurunan pendapatan pekerja yang tidak terkena PHK. Dari responden yang diteliti, terdapat 31,0 persen pekerja yang mengaku pendapatannya menurun kurang dari 50 persen dan 8,6 persen pekerja yang pendapatannya menurun di atas 50 persen. 
Kelompok usia muda merupakan kelompok paling rentan terkena PHK sehingga perlu mendapat perhatian khusus. Data penelitian menunjukkan terjadinya PHK yang sangat besar pada pekerja usia muda 15-24 tahun yaitu 34,5 persen (Tabel 1). Rentannya pekerja muda ini telah diprediksi oleh ILO (2020c) yang memperkirakan satu dari enam pekerja muda akan kehilangan pekerjaan pada masa pandemi COVID-19. Lebih lanjut, diperkirakan akan terjadi penurunan jam kerja hingga 23 persen pada seluruh pekerja muda. PHK pekerja muda yang tinggi akibat COVID-19 juga terjadi pada negara-negara maju di dunia. Montenovo dkk., (2020) menyatakan bahwa selama dua bulan pandemi COVID19, pekerja muda di Amerika Serikat menurun 4,5 kali lebih besar dibanding selama resesi tahun 2007-2008.

Berbagai program telah dilakukan untuk meningkatkan ketahanan pekerja muda terhadap goncangan ekonomi. Sejak tahun 2003, Indonesia telah membentuk Indonesia Youth Employment Network (IYEN) yang bertujuan untuk mengatasi pengangguran usia muda, bahkan inisiatif ini didukung oleh 17 kementerian (ILO, 2016). Namun implementasi dari program ini belum cukup berhasil menekan angka pengangguran pekerja usia muda.

COVID-19 telah menghantam semua sektor dan jenis pekerjaan di Indonesia dengan tingkat keparahan yang berbeda. Dcode (2020) memperkirakan terdapat beberapa sektor yang berpotensi kalah dan menjadi pemenang dalam jangka pendek akibat COVID-19. Layanan kesehatan, pengolahan dan perdagangan makanan, e-commerce dan teknologi informasi \& komunikasi berpotensi menjadi pemenang, sedangkan pariwisata, transportasi, dan konstruksi menjadi sektor yang berpotensi kalah. Tabel 1 menunjukkan jenis pekerjaan/jabatan yang paling banyak terkena PHK adalah tenaga usaha jasa (28,3 persen) dan tenaga usaha penjualan (26,4 persen). Selain mengalami PHK, sebagian pekerja juga mengalami penurunan pendapatan. Dalam keseluruhan jenis jabatan, terdapat 24-44 persen pekerja yang pendapatannya menurun kurang dari 50 persen. Selain itu, terdapat 5-16 persen pekerja yang pendapatannya menurun hingga lebih dari 50 persen (Tabel 2).

Berdasarkan Tabel 2, terdapat sektor-sektor zona merah yang mengalami PHK cukup tinggi, yaitu sektor konstruksi (29,3 persen) dan sektor perdagangan, rumah makan dan jasa akomodasi (28,9 persen). Kejadian PHK paling parah terjadi di sektor konstruksi karena seluruh korban PHK tidak mendapatkan pesangon. Keadaan hampir sama terjadi pada sektor perdagangan, rumah makan dan jasa akomodasi. Pada sektor ini sekitar 26,1 persen pekerja yang terkena PHK tidak mendapatkan pesangon. Para korban PHK yang tidak mendapat pesangon ini umumnya berstatus sebagai pegawai tidak tetap atau karyawan kontrak yang upahnya berdasarkan output tertentu. Banyak tempat rekreasi yang tutup dan kegiatan kontruksi bangunan yang terhenti, sehingga karyawannya berhenti bekerja tanpa mendapatkan pesangon. PHK akibat COVID-19 juga terjadi di negara-negara lain di dunia. ILO memperkirakan bahwa sekitar 47 juta yang mewakili 54 persen dari semua pengusaha di seluruh dunia juga dihantam krisis karena COVID-19. Empat sektor yang sangat terpukul adalah (a) sektor perdagangan grosir dan eceran; dan perbaikan kendaraan bermotor, (b) manufaktur, (c) akomodasi dan makanan, (d) real estate, aktivitas bisnis dan administrasi (ILO, 2020c).

Dampak COVID-19 terhadap tenaga kerja bervariasi antar daerah sebagaimana terlihat pada Tabel 2 . Wilayah dengan jumlah kasus PHK paling tinggi terjadi di Bali- Nusa Tenggara (39,9 persen) dan Banten (24,8 persen). Selain mengalami PHK, sebagian buruh/pekerja di Bali mengalami penurunan pendapatan $\mathrm{di}$ atas 50 persen $(16,7$ persen). Perekonomian Bali digerakkan oleh 3 sektor utama, yaitu sektor pariwisata, industri pengolahan, dan pertanian (BPS Provinsi Bali, 2019). Beberapa usaha yang digerakkan oleh sektor pariwisata di Bali diantaranya adalah kegiatan biro perjalanan, transportasi, perhotelan, restoran dan rumah makan, kesenian dan budaya daerah, industri kerajinan rakyat, serta tempat hiburan dan rekreasi. Pandemi COVID-19 menyebabkan kinerja sektor ini lumpuh sehingga memPHK cukup banyak pekerja. Bahkan kasus PHK tanpa pesangon di provinsi ini merupakan yang tertinggi di Indonesia (35,3 persen).

Banten juga menjadi provinsi dengan jumlah PHK cukup tinggi. Selain PHK, sebagian buruh/pegawai/karyawan juga mengalami penurunan pendapatan. Sekitar 10,1 persen responden mengaku mengalami penurunan pendapatan di atas 50 persen, sedangkan 39,2 persen responden pendapatannya 
Jurnal Kependudukan Indonesia | Edisi Khusus Demografi dan COVID-19, Juli 2020 | 43-48

menurun kurang dari 50 persen. Berbeda dengan Bali, ekonomi Banten yang dominan digerakkan oleh sektor industri pengolahan, konstruksi, dan perdagangan mengalami penurunan kinerja sebagai dampak dari COVID-19 (BPS Provinsi Banten, 2019). Perselisihan hubungan industrial berupa PHK tanpa pesangon di provinsi ini juga menempati posisi tertinggi ke-dua di Indonesia, yaitu sebesar 19,2 persen. Tingginya perselisihan industrial di wilayah ini menyebabkan Bali dan Banten masuk menjadi wilayah zona merah dalam hal kerawanan ketenagakerjaan.

Tabel 2.

PHK dan Perubahan Pendapatan Buruh/Pegawai/Karyawan Menurut Sektor Pekerjaan dan Lokasi Pekerjaan

\begin{tabular}{|c|c|c|c|c|c|c|c|c|}
\hline \multirow[b]{2}{*}{ Kategori } & \multicolumn{3}{|c|}{ PHK (\%) } & \multicolumn{4}{|c|}{ Perubahan pendapatan $(\%)$} & \multirow[b]{2}{*}{$\mathbf{n}$} \\
\hline & Total & $\begin{array}{c}\text { Tanpa } \\
\text { Pesangon }\end{array}$ & $\begin{array}{l}\text { Dengan } \\
\text { Pesangon }\end{array}$ & $\begin{array}{c}\text { Menurun } \\
<50 \%\end{array}$ & $\begin{array}{c}\text { Menurun } \\
\geq 50 \%\end{array}$ & $\begin{array}{c}\text { Tetap/ } \\
\text { meningkat }\end{array}$ & $\begin{array}{l}\text { Tidak ada } \\
\text { pendapatan }\end{array}$ & \\
\hline \multicolumn{9}{|l|}{ Sektor Pekerjaan } \\
\hline Industri Pengolahan & 22,2 & 18 & 4,3 & 46,9 & 8,5 & 31,2 & 13,4 & 10.523 \\
\hline Jasa Kemasyarakatan & 7,9 & 7 & 0,8 & 31,4 & 8,8 & 51 & 8,8 & 35.804 \\
\hline $\begin{array}{l}\text { Konstruksi/Bangunan } \\
\text { Lembaga Keuangan, Real }\end{array}$ & 29,3 & 29,3 & 0 & 37,4 & 10,1 & 27 & 25,5 & 3.541 \\
\hline $\begin{array}{l}\text { Estate, Usaha Persewaan \& } \\
\text { Jasa Perusahaan }\end{array}$ & 11,7 & 9,8 & 1,9 & 29,7 & 3,1 & 56,4 & 10,8 & 18.242 \\
\hline $\begin{array}{l}\text { Listrik, Gas, dan Air } \\
\text { Minum }\end{array}$ & 28,6 & 24,1 & 4,5 & 14,3 & 0 & 57,1 & 28,6 & 1.841 \\
\hline $\begin{array}{l}\text { Perdagangan, Rumah } \\
\text { Makan dan Jasa Akomodasi }\end{array}$ & 28,9 & 26,1 & 2,8 & 27 & 18,6 & 22,1 & 32,4 & 14.156 \\
\hline $\begin{array}{l}\text { Pertambangan dan } \\
\text { Penggalian }\end{array}$ & 11,2 & 11,2 & 0 & 35,4 & 0 & 50,7 & 13,9 & 2.657 \\
\hline $\begin{array}{l}\text { Pertanian, Perkebunan, } \\
\text { Kehutanan, Perburuan \& } \\
\text { Perikanan }\end{array}$ & 4,1 & 4,1 & 0 & 19 & 5 & 71,9 & 4,1 & 5.515 \\
\hline $\begin{array}{l}\text { Transportasi, Pergudangan, } \\
\text { dan Komunikasi }\end{array}$ & 2,9 & 26,4 & 23,4 & 25,6 & 9,3 & 39,6 & 25,5 & 8.465 \\
\hline \multicolumn{9}{|l|}{ Lokasi Kerja } \\
\hline Sumatera & 21,1 & 17,6 & 3,4 & 23,8 & 9,2 & 48,6 & 18,3 & 13.920 \\
\hline Bali dan Nusa tenggara & 39,9 & 35,3 & 4,6 & 17,5 & 16,7 & 23,6 & 42,2 & 4.815 \\
\hline Banten & 24,8 & 19,2 & 5,6 & 39,2 & 10,1 & 27,5 & 23,2 & 4.294 \\
\hline DI Yogyakarta & 7,6 & 7,6 & 0 & 18,3 & 1,5 & 72,6 & 7,6 & 4.093 \\
\hline DKI Jakarta & 11,8 & 10,2 & 1,6 & 30,8 & 6,8 & 48,9 & 13,5 & 38.673 \\
\hline Jawa Barat & 15,3 & 14,2 & 1 & 41,8 & 11 & 36,9 & 10,3 & 15.994 \\
\hline Jawa Tengah & 8,5 & 8,5 & 0 & 32,6 & 12,4 & 47,4 & 7,7 & 6.594 \\
\hline Jawa Timur & 10,4 & 10,4 & 0 & 28,7 & 8,6 & 48,5 & 14,2 & 6.084 \\
\hline Kalimantan & 12,6 & 12,6 & 0 & 29,1 & 7,6 & 49,9 & 13,5 & 3.805 \\
\hline Lainnya & 32,3 & 27,7 & 4,6 & 38,9 & 3,4 & 32 & 25,7 & 2.472 \\
\hline
\end{tabular}

Sumber: Analisis data primer

DKI Jakarta yang menjadi barometer perekonomian Indonesia juga tidak terlepas dari PHK karyawan pada saat pandemi COVID-19. Sekitar 11,8 persen karyawan/buruh di Jakarta menjadi korban PHK. Sebagian karyawan yang tidak terkena PHK juga mengalami penurunan pendapatan. Tercatat 6,8 persen karyawan mengalami penurunan pendapatan 50 persen ke atas dan 30,8 persen mengalami penurunan pendapatan kurang dari 50 persen. Tampak gelombang
PHK di Jakarta lebih rendah dibandingkan dengan Bali dan Nusa Tenggara. Meskipun demikian, 11,8 persen PHK karyawan tetap menjadi kejadian yang sangat merugikan dan perlu segera diantisipasi. Gelombang PHK dikhawatirkan akan semakin besar jika PSBB berlangsung dalam waktu lama karena sebagian besar kegiatan produksi barang dan jasa terhenti. 
Menurut UU No.13 Tahun 2003 tentang Ketenagakerjaan, PHK perlu dilakukan dalam beberapa proses, diantaranya adalah musyawarah antara pengusaha dan serikat pekerja/buruh. Jika tidak menghasilkan persetujuan, jalan terakhir adalah melalui pengadilan untuk penyelesaian perselisihan. Sebagai tanggung jawab perusahaan terhadap tenaga kerja yang telah di PHK, perusahaan wajib memberi uang pesangon, uang penghargaan, atau uang penggantian hak bagi pegawai (pasal 156 dan pasal 160-169). Lebih

\section{KESIMPULAN}

Pandemi COVID-19 menyebabkan 15,6 persen pekerja di Indonesia terkena PHK, bahkan 13,8 persennya tidak mendapatkan pesangon. Pekerja ter-PHK ini mayoritas dari kalangan pekerja usia muda 15-24 tahun. Beberapa sektor terparah yang perlu menjadi perhatian khusus adalah sektor konstruksi (29,3 persen), sektor perdagangan, rumah makan dan jasa (28,9 persen), dan sektor transportasi, pergudangan dan komunikasi $(26,4$ persen). PHK tanpa pesangon merupakan salah satu bentuk pelanggaran UU No.13 Tahun 2003 terkait ketenagakerjaan.

Untuk mengatasi pelanggaran ini, pemerintah perlu melakukan pengawasan ketat terhadap perusahaan di masing-masing wilayah. Bentuk pengawasannya tidak hanya berupa labour inspection, tapi juga pengawasan yang bersifat mandatori. Labour inspector, sesuai dengan Konvensi ILO K-81 tidak boleh dihalangi untuk melakukan pengawasan dan pemeriksaan jika ada surat perintah (ILO, 2009). Dengan dikeluarkannya Surat Edaran (SE) Menteri Ketenagakerjaan Nomor M/3/HK.04/III/2020 tentang Perlindungan Pekerja/Buruh dan Kelangsungan Usaha dalam Rangka Pencegahan dan Penanggulangan COVID-19, Gubernur diminta untuk melaksanakan pelindungan pengupahan bagi pekerja/buruh serta kelangsungan usaha.

Pandemi ini telah mengakibatkan banyak kerugian. Oleh karena itu, masyarakat perlu mencari strategi baru dengan memanfaatkan teknologi dan mencari peluang kerja baru, namun tetap memperhatikan protokol kesehatan. Tanpa melonggarkan PSBB, alternatif untuk menumbuhkan perekonomian di beberapa sektor perlu dipikirkan. Artinya, protokol kesehatan tetap berlaku, tapi roda ekonomi di beberapa sektor dapat lebih lanjut, terdapat batasan-batasan yang membolehkan pengusaha untuk melakukan PHK, sehingga tidak boleh dilakukan secara sepihak dan sewenang-wenang. PHK tanpa pesangon juga merupakan salah satu pelanggaran dari undang-undang tersebut dan tergolong industrial abuse. Pandemi COVID-19 tidak bisa dijadikan pembenaran bagi perusahaan untuk membuat kebijakan yang secara normatif melanggar hak asasi pekerja untuk mendapatkan pesangon.

dihidupkan. Seperti misalnya pedagang di Salatiga yang tetap berdagang tetapi mereka menjaga jarak antar lapak dan pengunjung tetap menaati protokol kesehatan. Dalam hal ini, kurang lebih 90 persen pedagangnya telah menaati peraturan tersebut (Pemerintah Kota Salatiga, 2020).

\section{DAFTAR PUSTAKA}

Badan Pusat Statistik Provinsi Bali [BPS Provinsi Bali]. (2019). Provinsi bali dalam angka 2019. Denpasar: BPS Provinsi Bali.

Badan Pusat Statistik Provinsi Banten [BPS Provinsi Banten]. (2019). Provinsi Banten dalam angka 2019. Serang: BPS Provinsi Banten.

Cox. (2020). Coronavirus job losses could total 47 million, unemployment rate may hit $32 \%$, fed estimates. Retrieved May 17, 2020. https://www.cnbc.com/2020/03/30/coronaviru s-job-losses-could-total-47-millionunemployment-rate-of-32percent-fedsays.html

Dcode, E. (2020). Infographics- decoding the economics of Covid-19. https://dcodeefc.com/infographics

International Labour Organization [ILO]. (2009). K-81 Pengawasan ketenagakerjaan dalam industri dan perdagangan. Geneva: International Labour Organization.

. (2016). Youth employment policy summary Indonesia. Geneva: International Labour Organization.

. (2020a). COVID-19 dan world of work: Impact and policy responses. Geneva: International Labour Organization. 
Jurnal Kependudukan Indonesia | Edisi Khusus Demografi dan COVID-19, Juli 2020 | 43-48

ILO. (2020b). ILO monitor: Covid-19 and the world of work ( $2^{\text {nd }}$ ed.). Geneva: International Labour Organization.

ILO. (2020c). ILO monitor: Covid-19 and the world of work ( $3^{\text {nd }}$ ed.). Geneva: International Labour Organization.

Montenovo, L., Rojas, X., Schmutte, F., Simon, I., Weinberg, K., \& Wing, B. (2020). Determinants of disparities in Covid-19 job losses. NBER Working Paper Series.

Ozili, P., \& Arun, T. (2020). Spillover of Covid-19: Impact on the global economy. SSRN Electronic Journal.
Pemerintah Kota Salatiga. (2020). 90\% pedagang pasar pagi Salatiga taati protokol kesehatan "physical distancing." Retrieved April 29, 2020). http://salatiga.go.id/90-pedagang-pasarpagi-salatiga-taati-protokol-kesehatanphysical-distancing/

Ziv, S. (2020, Mei 10). Don't be fooled by official unemployment rate of $14.7 \%$, The real figure is even scarier. forbes. https://www.forbes.com/sites/shaharziv/2020/ 05/10/dont-be-fooled-by-officialunemployment-rate-of-147-the-real-figure-iseven-scarier/\#5181baa455dd http://doi.org/10.2139/ssrn.3562570 